\title{
Zeytin Karasuyunun Anaerobik Arıtılabilirliği ve Biyogaz Üretim Potansiyelinin Araştırılması
}

\author{
Fatih TUFANER ${ }^{1,2 *}$ \\ ${ }^{1}$ Adlyaman Üniversitesi, Mühendislik Fakültesi, Çevre Mühendisliği Bölümü, Adlyaman, Türkiye \\ ${ }^{2}$ Adıyaman Üniversitesi, Çevre Yönetimi Uygulama ve Araştırma Merkezi, Adıyaman, Türkiye \\ (ORCID: 0000-0002-1286-7846)
}

\begin{abstract}
$\ddot{O} z$
Zeytinyağı üretim fabrikalarında zeytin karasuyunun anaerobik olarak arıtılması hem biyogaz üretimi hem de sürdürülebilir çevre için umut verici bir yöntemdir. Bununla birlikte zeytinyağı fabrikalarının dönemsel çalışıyor olması bir dezavantaj gibi görünse de geniş zaman imkanı ile yüksek organik yüke sahip olan zeytin karasuyunun gerekli seyreltme ve baz ilavesi gibi ön işlemler ile arıtılması mümkündür. Bu çalışmada, yaklaşık $78000 \mathrm{mg} / \mathrm{L}$ KOİ konsantrasyonuna sahip ham zeytin karasuyu yaklaşık $1 / 8$ oranında musluk suyu ile seyreltilerek $6,15 \mathrm{~L}$ aktif hacme sahip yukarı akışı havasız çamur yataklı anaerobik reaktörde mezofilik şartlarda $\left(37 \pm 0,5^{\circ} \mathrm{C}\right)$ arıtılmıştır. Deneysel çalışma esnasında zeytin karasuyunun fiziksel ve kimyasal yapısından kaynaklanabilecek olumsuzlukların önüne geçerek gerekli mikroorganizma adaptasyonunun sağlanabilmesi için 39 günlük bir kesikli besleme süreci ile proses deneysel çalışmaya hazırlanmıştır. Hidrolik besleme süresinin 10 gün organik yükleme oranının $1 \mathrm{~kg} \mathrm{KOI்} / \mathrm{m}^{3} / g u ̈ n$ olduğu anaerobik proses 32 gün boyunca yarı sürekli olarak beslenmiştir. Düşük alkaliniteye sahip olduğu için $615 \mathrm{~mL}$ seyreltilmiş zeytin karasuyunun $(10000 \mathrm{mg} \mathrm{KOİ} / \mathrm{L})$ anaerobik arıtımı $1 \mathrm{~N}$ $12 \mathrm{~mL} \mathrm{NaOH}$ ilavesi ile $\mathrm{pH}$ 6,8-7,2 aralığında gerçekleştirilmiştir. Çalışmanın sonunda \%75,6 $( \pm 14,2)$ KOİ giderimi ile birlikte 2177 ( \pm 279$) \mathrm{mL} /$ gün biyogaz üretiminin gerçekleştiği tespit edilmiştir. Anaerobik arıtma, seyreltilerek alkalinite takviyesi yapılmış olan zeytin karasuyundan KOİ giderimi ve biyogaz üretimi için sürdürülebilirlik açısından ve çevresel olarak dikkate alınması gereken bir prosestir.
\end{abstract}

Anahtar kelimeler: Zeytin Karasuyu, Anaerobik Arıtma, KOİ Giderimi, Biyogaz Üretimi.

\section{Investigation of Anaerobic Treatability and Biogas Production Potential of Olive Mill Wastewater}

\section{Abstract}

Anaerobic treatment of olive mill wastewater in olive oil production plants is a promising method for both biogas production and environmental sustainability. Moreover, it is possible to treat the olive mill wastewater which has high organic load with the opportunity of wide time, with the necessary dilution and base adding, although it seems to be a disadvantage that the olive oil mills operate seasonally. In this study, raw olive mill wastewater with a COD concentration of approximately $78000 \mathrm{mg} / \mathrm{L}$ was diluted with tap water at a rate of about $1 / 8$ and treated in an upflow anaerobic sludge blanket reactor under mesophilic conditions $\left(37 \pm 0.5^{\circ} \mathrm{C}\right)$ with an active volume of 6.15 L. During the experimental study, the system was prepared for an experimental study with 39 days batch feeding process in order to provide the necessary microorganism adaptation by preventing the negative effects that may arise from the physical and chemical structure of the olive mill wastewater. The anaerobic process was fed semicontinuous for 32 days, where the hydraulic retention time was 10 days and the organic loading rate was $1 \mathrm{~kg}$ $\mathrm{COD} / \mathrm{m}^{3} /$ day. The low alkalinity of olive mill wastewater was challenging for the anaerobic process. Approximately $615 \mathrm{~mL}$ (10000 mg/L COD) diluted olive mill wastewater by adding $1 \mathrm{~N} 12 \mathrm{~mL} \mathrm{NaOH}$ was brought to the appropriate $\mathrm{pH}$ range for anaerobic conditions (6.8-7.2). At the end of the study, it was determined that 2177 $( \pm 279) \mathrm{mL}$ /day biogas production was realized with $75.6 \%( \pm 14.2) \mathrm{COD}$ removal. Anaerobic treatment is a process that must be considered in terms of sustainability and environment for COD removal and biogas production from olive mill wastewater which has been diluted and supplemented alkalinity.
\end{abstract}

Keywords: Olive Mill Wastewater, Anaerobic Treatment, COD Removal, Biogas Production

\footnotetext{
*Sorumlu yazar: ftufaner@adiyaman.edu.tr

Geliş Tarihi: 18.01.2020, Kabul Tarihi: 08.05.2020
} 


\section{Giriş}

Yüksek ekonomik değere sahip olmasının yanı sıra sağlık açısından yararlı bir besin olduğu bilinen zeytinyağ 1 özellikle Akdeniz çevresindeki ülkelerde önemli bir üretim potansiyeline sahiptir [1,2]. Türkiye'de 2000'li yılların başında yaklaşık 100 milyonu bulan zeytin ağacı sayısının 2018-2019 yıllarındaki dikimlerle beraber 178 milyona ulaştı̆ı bildirilmiştir [3]. Türkiye'de zeytinyağı üretimi bir önceki sezona göre 2017-2018 sezonunda \%48 artışla 263000 tona ulaşmıştır [4]. 2018-2019 sezonunda ise 189212 ton zeytinyağı üretimi yapılmıștır. Ayrıca 2019-2020 sezonunda zeytinyağı üretiminin bir önceki yıla göre \%18,7 artış ile yaklaşık olarak 224595 ton olacağı tahmin edilmektedir [5]. Bununla birlikte, dünya çapında 2018-2019 sezonunda 3,218 milyon ton zeytinyağı üretimi yapılmış olup 20192020 sezonunda ise yıllık olarak yaklaşık 3,144 milyon ton zeytinyağı üretiminin olacağ 1 tahmin edilmektedir [6]. Zeytinyağı üretimindeki bu artış eğilimi atık zeytin karasuyu (ZK) miktarına yansımaktadır. Zeytinyağı üretim prosesinde 1 ton zeytinin işlenmesi sonucunda yaklaşık $200 \mathrm{~kg}$ zeytinyağ 1 ve $600-1200 \mathrm{~kg}$ arasında ZK oluşmaktadır [7]. Türkiye İstatistik Kurumu (TÜIKI) [3] verilerine göre, 2018 yılında Türkiye'de yaklaşık 1 milyon ton yağlık zeytin üretilmiştir. Bu verilere göre 2018 yılında yaklaşık olarak 6-1,2×10 $0^{5}$ ton ZK oluşmuştur. Dünya genelinde 2014-2015 sezonunda bir yılda yaklaşık $5,4 \times 10^{6} \mathrm{~m}^{3} \mathrm{ZK}$ oluştuğu bildirilmiştir [8]. Bu rakamlara bakıldığında, birçok önemli çevre sorununun potansiyel bir kaynağı olan ZK oluşumunun, birçok ülkede çevre yönetimi açısından sorunlu bir konu olduğu anlaşılmaktadır.

ZK'nın miktarı ve fizikokimyasal bileşimi, toprak ve iklim koşulları, tarımsal yöntemler, zeytinin türü, zeytin ağacının yaşı, zeytinin olgunlaşma seviyesi ve zeytinyağı çıkarma yöntemi gibi çeşitli faktörlere bağlıdır [9, 10]. Yağı ayrılan zeytin meyvesinin suyundan ve zeytinyağı çıkarma prosesi esnasında prosese ilave edilen sudan oluşan ZK asidik bir $\mathrm{pH}(4,80$ - 5,50) değerine sahip siyahkırmızı renkli bir atıksudur [11]. Genel olarak, katı sıvı karışımı bir yapıya sahip olan ZK su, yağ asitleri, karbonhidratlar ve polifenollerden oluşmaktadır [10]. Tipik olarak, ZK \%83-96 su, \%3,5-15 organikler ve \%0,5-2 arasında mineral tuzlardan oluşmaktadır. ZK'nın organik fraksiyonu ise fenoller ve pektinlerin (\%1-1,5) yanı sıra şekerler (\%1-8), N-bileşikleri $(\% 0,5-2,4)$, organik asitler $(\% 0,5-1,5)$ ve yağlardan (\%0,02-1) oluşmaktadır [12]. ZK 30'dan fazla fenolik bileşik ve şeker içermektedir [13]. Farklı kaynaklarda birbirinden bağımsız olarak kimyasal oksijen ihtiyacı (KOİ) ve biyolojik oksijen ihtiyacı (BOİ) değerlerinin sırasıyla 40-220 g/L ve 35-110 g/L sınırları içerisinde değerler aldığı ifade edilmiştir [14]. Bununla birlikte, fenolik bileşikler, organik asitler ve tanenler gibi çeşitli organik bileşiklerin yüksek konsantrasyonları ile karakterize edilen ZK, biyolojik işleme karşı oldukça dirençlidir [15]. Bu nedenle, Lucas ve Peres'in çalışmasında olduğu gibi ZK'nın arıtılmasında KOİ parametresinin takibi daha doğru olacaktır [16]. Bununla birlikte, zeytinyağı üretimi için ülkemizde Su Kirliliği Kontrolü Yönetmeliğinde alıcı ortam deşarj standartlarında sadece KOİ, yağ ve gres, pH ve renk parametreleri belirtilmiştir [1].

Su yollarına deşarj edilen ZK, su kütlesinin genel yapısını bozulması ile su ekosistemine önemli zararlar vererek koku, su kirliliği ve yeraltı suyu kirliliği gibi önemli derecede çevresel problemlere sebep olmaktadır. Ayrıca, ZK'nın yetersiz veya kontrolsüz arıtımı ve deşarj edilmesi durumunda da su ekosistemine ciddi zararlar vermektedir. ZK'nın arıtılmas1, yüksek kirlilik potansiyeli ve mevcut yasal düzenlemelerin kademeli olarak sıkılaştırılması nedeniyle zeytinyağı üreticileri için sıkıntı veren bir endişeye dönüşmüştür. $\mathrm{Bu}$ nedenle zeytinyağı üretim endüstrisi için ekonomik ve çevresel sürdürülebilirliği birleştirebilen uygun arıtma prosesleri önemli bir gereksinimdir [2, 17]. Son zamanlarda, ultrafiltrasyon [18], nanofiltrasyon [19], ters ozmoz [20], buharlaşma-yoğuşma [21], güneşte kurutma [22], koagülasyon-flokülasyon [23], oksidasyon [24] ve ozonlama [25] gibi fizikokimyasal yöntemler ve aerobik-anaerobik proses [26] ve kompostlaştırma prosesi [27] gibi biyolojik yöntemler ZK'yı arıtmak için yaygın olarak uygulanmıştır. ZK'nın fizikokimyasal ve biyolojik arıtma prosesleri ile arıtılmaya çalışıldığı son çalışmalarda, giderilmesi zor olan fitotoksik kirleticilerin ZK'nın arıtılmasını zorlaştırdığı vurgulanmıştır. Ayrıca, ZK'nın geniş bir fizikokimyasal bileşime sahip olması, zeytinyağı fabrikalarının küçük ölçeklerde olması, coğrafi olarak bu fabrikaların dağılımı ve mevsimsel üretim yapılması gibi nedenlerden dolayı günümüze kadar etkin ve uygun maliyetli arıtım süreçleri istenildiği gibi uygulanamamıştır. Yani, küresel olarak uygulanabilecek yaygın bir arıtma yöntemi ve kesin bir strateji bulunmamakla beraber merkezi bir arıtmada mümkün görünmemektedir. Ancak, zeytinyağı fabrikalarının mevsimsel çalışmasından dolayı anaerobik arıtma sistemlerinin bir dönem kapatıldıktan sonra kolayca yeniden devreye alınabildiği için bir dezavantaj olmadığı ifade 
edilmiş̧ir [28]. Genellikle birleşik arıtma konfigürasyonları uygulanmakla beraber Fenton prosesinin maliyet verimliliği açısından uygun gibi göründügü ifade edilmiştir [29]. Birçok ülkede benimsenen çözüm ZK'nın açık havuzlarda buharlaştırılmasıdır. Ancak, bu havuzlar kötü koku, metan emisyonu, toprağa sızma, böcek ve sineklerin çoğalması ve buharlaştırma için geniş alanlar gerektirmesi gibi olumsuz yönlerinden dolayı bu sorunu çözmek için etkili bir metot olmadığı anlaşılmaktadır [30]. Sonuç olarak, Akdeniz bölgesinde zeytinyağı üretimi neticesinde önemli hacimlerdeki ZK su yollarına deşarj edilmektedir [31,32]. Fayda maliyet oranını arttırabilmek ve bu çevresel problemin üstesinden gelebilmek için sürdürülebilir arıtma teknolojilerinin kullanılmasının gerekliliği açıktır. Biyolojik prosesler çevre dostu ve çoğu durumda uygun maliyetli arıtma yöntemi olarak kabul edilmektedir [33]. Anaerobik arıtma, ZK'nın arıtılması için umut verici teknolojilerden biri olarak bildirilmiştir $[30,34,35]$. Anaerobik proses, yenilenebilir bir enerji kaynağı olan biyogaz üretiminin yanı sıra, düşük çamur üretimi, düşük besin gereksinimi, sera gazı emisyonlarının azaltılması ve sıvı gübre üretimi gibi pozitif yönleriyle oldukça avantalı bir arıtma yöntemi olarak karşımıza çıkmaktadır. Bununla birlikte, asidik bir $\mathrm{pH}$ değerine sahip olması, düşük alkalinite, düşük azot içeriği, zeytin çekirdeği ve meyvesinin işlenmesi neticesinde oluşan fenolik bileşikler ve lipit fraksiyonlarının varlığı gibi çeşitli ZK özellikleri, bu atıksuyu potansiyel toksik bir substrat haline getirir ve sonuç olarak bu durum anaerobik biyosistem için uygun değildir. Bu sorunların üstesinden gelmek için çeşitli sentetik besin maddeleri, kimyasal ilaveler ve su ile seyreltilmesinin yanı sıra ön işlem uygulamalarının (kimyasal ve biyokimyasal) ZK'nın anaerobik olarak arıtılmasını mümkün kıldığı bildirilmiştir [31, 32, 36-39]. Bununla birlikte, ön arıtma işlemleri genellikle metanojenik aktiviteyi yavaşlattı̆̆ 1 bilinmekte ve arıtma maliyetlerinin artmasına sebep olmaktadır [39]. Anaerobik bir reaktörün stabilitesi, reaktördeki yeterli alkalinite seviyeleri ile muhafaza edilebilir. Çoğu durumda, ZK yeterli alkaliniteye sahip olmadığından, anaerobik reaktörlere $\mathrm{NaOH}$ [40], $\mathrm{Ca}(\mathrm{OH})_{2}$ [31], $\mathrm{NaHCO}_{3}$ [41], ve $\mathrm{Ca}\left(\mathrm{HCO}_{3}\right)_{2}$ [42] dahil olmak üzere harici alkali kimyasallar eklenmiştir. ZK atıksularının anaerobik arıtımı yaygın olarak mezofilik sıcaklık aralıklarında $\left(32-40{ }^{\circ} \mathrm{C}\right)$ gerçekleştirilmiştir. Bununla birlikte, termofilik şartlarda $\left(55^{\circ} \mathrm{C}\right)$ çok az sayıda çalışma yapılmıştır [43].

Bu çalışma Türkiye'de önemli bir üretim potansiyeline sahip olan zeytinyağı üretimi neticesinde oluşan ZK'nın anaerobik proses ile verimli bir şekilde arıtılabilirliğini ve biyogaz üretim potansiyelini araştırmak için yapılmışırır.

\section{Materyal ve Metot}

\subsection{Zeytin Karasuyu ve Aşı Çamuru}

Deneysel çalışmada kullanılan ZK Adıyaman Organize Sanayi Bölgesinde (AOSB) üç fazlı yönteme göre zeytinyağı üretimi yapan Ünal Han Yağı ve Küspe Fabrikası'ndan temin edilmiştir. Deneysel çalışmalarda kullanılmadan önce ayrışmasını önlemek maksadıyla $\mathrm{ZK}+4{ }^{\circ} \mathrm{C}$ 'de buzdolabında muhafaza edilmiştir. AOSB atıksularının deşarj edildiği Eğriçay deresi sediment çamurunun anaerobik olarak arıtıldığ çalışma [44] sonrasında reaktörlerde kalan çamur deneysel çalışmada aşı çamuru olarak kullanılmıştır. Çalışmada kullanılan ZK'nın ve aşı çamurunun fizikokimyasal özellikleri Tablo 1'de verilmiştir.

Tablo 1. Çalışmada kullanılan zeytin karasuyu ve aşı çamurunun fizikokimyasal özellikleri

\begin{tabular}{lcc}
\hline \multirow{2}{*}{ Parametreler } & \multicolumn{2}{c}{ Değerler } \\
\cline { 2 - 3 } & $\begin{array}{c}\text { Aşı } \\
\text { Çamuru }\end{array}$ & $\begin{array}{c}\text { Zeytin } \\
\text { Karasuyu }\end{array}$ \\
\hline $\mathrm{pH}$ & 7,27 & 4,65 \\
$\mathrm{KOİ}(\mathrm{mg} / \mathrm{L})$ & 43330 & 78240 \\
$\mathrm{TKM}(\mathrm{mg} / \mathrm{L})$ & 43610 & 50450 \\
$\mathrm{UKM}(\mathrm{mg} / \mathrm{L})$ & 37180 & 37830 \\
Alkalinite $(\mathrm{mg} \mathrm{CaCO} / \mathrm{L})$ & 2336 & 2,13 \\
$\mathrm{TKN}(\mathrm{mg} / \mathrm{L})$ & 1949 & 582 \\
$\mathrm{NH}_{3}-\mathrm{N}(\mathrm{mg} / \mathrm{L})$ & 170 & 30 \\
$\mathrm{TP}(\mathrm{mg} / \mathrm{L})$ & 211 & 274 \\
$\mathrm{PO}_{4}-\mathrm{P}(\mathrm{mg} / \mathrm{L})$ & 37 & 96 \\
\hline
\end{tabular}




\subsection{Anaerobik Reaktör ve İşletme Şartları}

Deneysel çalışmada Şekil 1'de gösterilen 6,15 L aktif çalışma hacmine sahip olan yukarı akışlı havasız çamur yataklı reaktör (YAHÇYR) kullanılmıştır. Azbar ve ark. [45] YAHÇYR'de hidrolik bekleme süresi (HBS) 2,5-10 gün ve 0,45 ile $32 \mathrm{~kg} \mathrm{KOİ} / \mathrm{m}^{3} /$ gün arasındaki organik yükleme oranlar1 (OYO) arasında ZK atıksularının arıtma performansını incelemişlerdir. Çalışmalarında OYO'nun $10 \mathrm{~kg}$ $\mathrm{KOI} / \mathrm{m}^{3} /$ gün seviyesinden daha düşük oranlarda $\% 90$ 'ın üzerinde bir KOİ gideriminin olduğunu bildirmişlerdir. Ayrıca maksimum KOİ gideriminin 8 günlük HBS'de olduğunu gözlemlemişlerdir. Bir başka çalışmalarında ise anaerobik hibrit reaktörde maksimum KOİ gideriminin 10 günlük HBS'de gerçekleştiğini bildirmişlerdir [31]. Buna ilaveten araştırmacıların HBS'yi 5 ila 10 gün arasında tutmanın ZK'nın etkili bir şekilde arıtılmasına izin verdiğini ifade etmişlerdir [43].

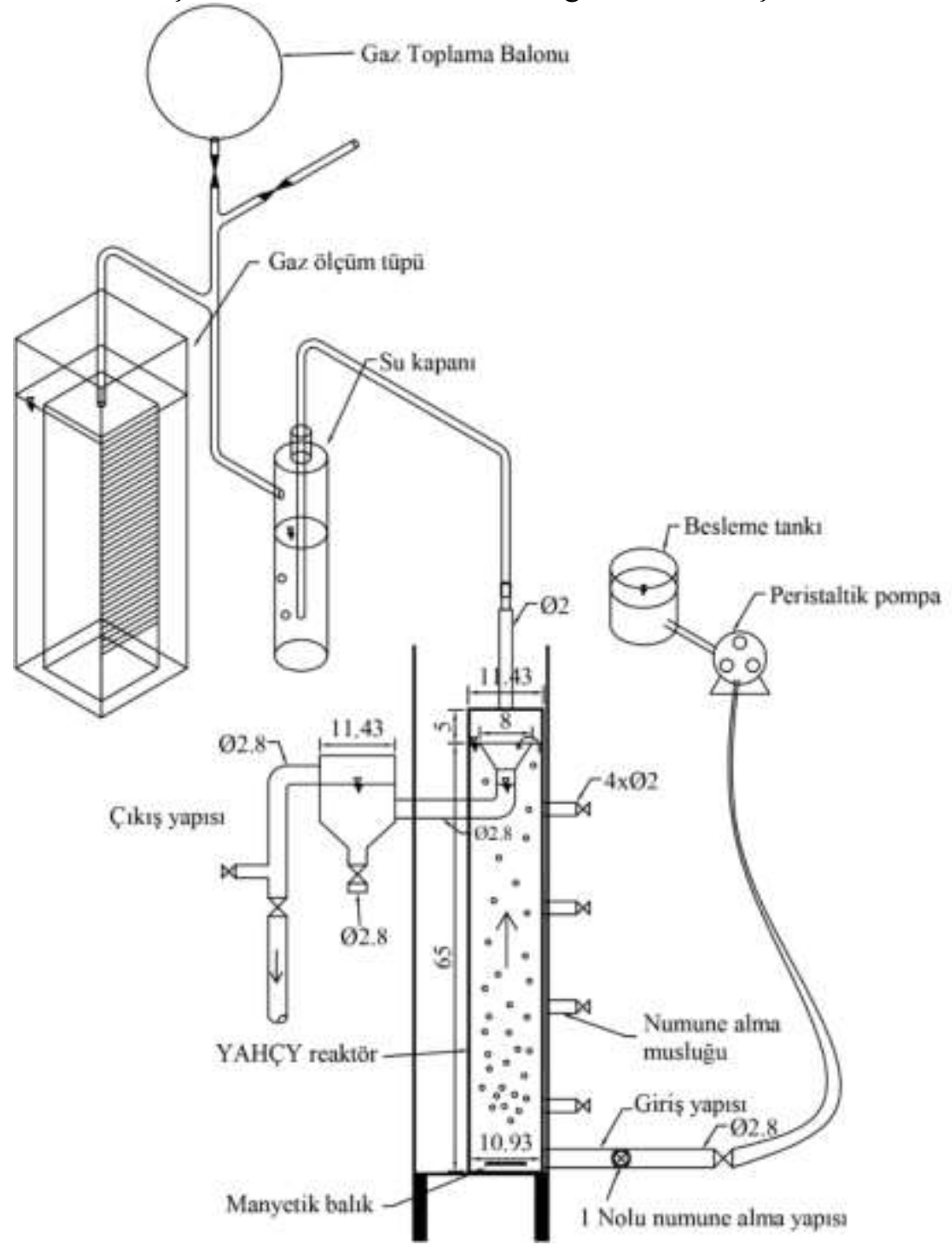

Şekil 1. Deneysel çalışmada kullanılan düzeneğin şematik görünümü

Bu çalışmada yüksek bir arıtma verimi elde edebilmek için YAHÇYR mezofilik şartlar $(37 \pm 0,5$ ${ }^{\circ} \mathrm{C}$ ) altında 10 günlük HBS ve $1 \mathrm{~kg} \mathrm{KOI} / \mathrm{m}^{3} /$ gün OYO ile işletilmiştir. Mezofilik şartların sağlanabilmesi için reaktör su ceketi içerisine yerleştirilmiştir. Sıcaklık kontrolü $0,1{ }^{\circ} \mathrm{C}$ hassasiyetli bir termostat (EMKO marka ESM-3710) ve termostat kontrolünde devreye giren iki adet bakır rezistans (THERMOGERM marka TH-50 model) ile sağlanmıştır. Su ceketi içerisindeki sıcaklık dağılımını dengelemek için su ceketinin tabanından aldığ 1 suyu su ceketi üst noktasına aktaran sirkülasyon pompası (LEO marka LRP32-60/180 model) kullanılmıştır. Devridaim işlemi, ayarlanan sıcaklık değerinden istenen sıcaklık değerine ulaşılana kadar devam etmektedir. Deneysel çalışma kesikli ve yarı sürekli beslemenin yapıldığ iki periyotta gerçekleştirilmiştir. Beslemede kullanılan ham ZK musluk suyuyla $1 / 8$ oranında seyreltilmiştir. İlk periyotta aşı çamurunun ZK'ya adaptasyonu için anaerobik reaktöre 3 
L aş1 çamuru ve $3 \mathrm{~L}$ seyreltilmiş ZK (kesikli) besleme yapılarak anaerobik süreç 39 gün boyunca izlenmiştir. İkinci periyotta anaerobik reaktöre 32 gün boyunca yaklaşık olarak $10 \mathrm{~g} / \mathrm{L}$ KOİ konsantrasyonuna sahip olan 0,615 L ZK yarı sürekli olarak beslenmiştir. Yarı sürekli besleme anaerobik sistemde biyogaz üretimi kararlı hale (yaklaşık son 25 gün) gelene kadar devam ettirilmiştir. Sistem stabilitesinin korunması maksadıyla $\mathrm{pH}$, deneysel çalışma boyunca her gün ölçülmüş ve anaerobik sistemin $\mathrm{pH}$ '1, baz (1N NaOH çözeltisi) ilavesiyle 6,8 ile 7,2 arasında tutulmaya çalışıllmıştır. Yarı-sürekli besleme peristaltik bir pompa (LONGERPUMP marka BT100-2j model) ile yapılmıştır. Reaktörün karıştırılması, besleme yapılırken reaktörün tabanındaki manyetik balık ile gerçekleştirilmiştir. Deneysel çalışma daha önce başka çalışmalarda kullanılan ve ayrıntılı olarak tarif edilen YAHÇYR kullanılarak yürütülmüştür [2, 44, 46, 47].

\subsection{Analitik Metotlar}

Deneysel çalışmalarda tüm örnekler Standart Metotlarda belirtilen yöntemlere göre hazırlanmış ve analiz edilmiştir [48]. pH ölçümleri pH metre (Orion Star marka A211 model) ile gerçekleştirilmiştir. Alkalinite tayini (APHA SM (2012) 2320-B), numuneler çok renkli ve bulanık olduğundan dolayı pH metre kontrolünde, manyetik balık ile karıştırılırken $0,02 \mathrm{~N} \mathrm{H}_{2} \mathrm{SO}_{4}$ ile $\mathrm{pH} 4,2-4,5$ seviyesine kadar titre edilerek analiz edilmiştir. KOİ deneyleri Kapalı Reflux Kolorimetrik metodunda (APHA SM (2012) 5220-D) tarif edildiği gibi $600 \mathrm{~nm}$ dalga boyunda spektrofotometre (Hach Lange DR 6000) ile analiz edilmiştir. TKM tayini (APHA SM (2012) 2540-B), darası alınıp sabit tartıma getirilen porselen krozelere konulan bir miktar numune $103-105^{\circ} \mathrm{C}$ ' de etüvde (Nüve marka FN 500 model) kurutulduktan ve sabit tartıma getirildikten sonra hassas terazide (Axis marka AGN $220 \mathrm{C}$ model) tartılmış, baştaki dara sabit tartımı çıkartılmış ve numune miktarına bölünerek mg/L olarak TKM değeri belirlenmiştir. Aynı numune $550{ }^{\circ} \mathrm{C}$ 'de kül firınında 15 dakika yakıldıktan sonra sabit tartıma getirilip tekrar tartılmıştır. Porselen krozenin etüv çıkış ağırlığından kül fırını çıkış ağırlığı çıkartılıp numune miktarına bölünerek UKM değeri mg/L olarak hesaplanmıştır (APHA SM (2012) 2540-E). TKN tayininde (APHA SM (2012) 4500- $\mathrm{N}_{\text {org }}$ B) kuvvetli oksitleyici kullanılarak organik azot amonyak azotuna dönüştürülmüştür. Numunede bulunan amonyak ve amonyak azotuna dönüştürülen organik azot bazik ortamda distilasyon ünitesi vasıtasıyla borik asit çözeltisinde tutulmuştur. Daha sonra borik asit içerisinde tutulan amonyak miktarı $0,02 \mathrm{~N} \mathrm{H}_{2} \mathrm{SO}_{4}$ ile titre edildikten sonra $\mathrm{mg} / \mathrm{L}$ olarak hesaplanmıştır. Amonyak tayininde (APHA SM (2012) 4500- $\mathrm{NH}_{3} \mathrm{C}$ ) ise yüksek pH'ya getirilen numune içindeki amonyak, distilasyon sonrasında borik asit içerisinde tutulmuş ve sonra titrimetrik yöntemle tayin edilmiştir. TP analizinde (APHA SM (2012) 4500-P D) uygun oranda seyreltilmiş numuneye $\mathrm{H}_{2} \mathrm{SO}_{4}$ $\mathrm{HNO}_{3}$ asit ilavesi ile parçalama ve $\mathrm{pH}$ nötralizasyonu işlemleri uygulanmıştır. Daha sonra kalay klorür metodu kullanılarak oluşan mavi rengin spektorfotometrede $690 \mathrm{~nm}$ 'de absorbans değeri okunmuştur. Absorbans değeri, standartlarla oluşturulmuş kalibrasyon doğrusunun denkleminde yerine konularak ve seyreltmelerde hesaba katılarak TP değeri hesaplanmıştır. $\mathrm{PO}_{4}-\mathrm{P}$ değerinin belirlenmesinde ise TP analizindeki parçalama işlemi haricindeki diğer işlemler uygulanmıştır. Sistemde üretilen biyogazın hacmi deplasman yöntemine göre çalışan gaz ölçüm tüpleri $(10 \times 10 \times 40 \mathrm{~cm})$ ile yapılmıştır. Biyogaz bileşimi $\left(\mathrm{CH}_{4}, \mathrm{CO}_{2}\right)$ portatif biyogaz detektörü (ETG MCA 100 P, ETG Risorse e Tecnologia, Montiglio, İtalya) kullanılarak analiz edilmiştir.

\section{Bulgular ve Tartışma}

Aşı çamuru seçiminin biyokütle üretimi için gereken süreyi en aza indirmede önemli bir rol oynadığı bilinmektedir [49]. Dengeli bir mikrobiyal popülasyona sahip olan bir aşı çamuru, hızlı metan üretimi ve kararlı bir anaerobik prosesi sağlayabileceğinden dolayı substrat aşı çamuru oranı ve aşı çamurunun istenen substratlara adaptasyonu, anaerobik proseslerin başlangıç peryodunda dikkate alınması gereken önemli işletme kıstaslarındandır [50]. Ayrıca, optimal substrat aşı çamuru oranı ve adapte olmuş bir aşı, anaerobik proses gereksinimlerini azaltırken arıtma etkinliğini artırabilir [50-52]. Guendouz ve ark. [53] çalışmalarında biyogaz üretimindeki gecikmelerin mikroorganizmaların atıklara ve deney koşullarına olan adaptasyonuna bağlanabileceğini ifade etmişlerdir. Bu nedenle, seçilen aş1 çamurunun ZK'ya adapte olabilmesi için kesikli besleme yapılarak 39 günlük bir alışma süresinden sonra çalışma yarı sürekli besleme yapılarak 32 gün boyunca sürdürülmüştür. Deneysel çalışmada 39 günlük adaptasyon periyodundan sonra yapılan ilk besleme ile beraber biyogaz üretiminden olumlu sonuçlar alınmıştır. 
Calabrò ve ark. [17] deneysel çalışmalarında, anaerobik proseste besi maddesi olarak kullanılan ZK' daki polifenollere karşı mikrobiyal adaptasyonun katkılarını incelemişlerdir. Çalışmada mikrobiyal adaptasyonun olmaması durumunda $2 \mathrm{~g} / \mathrm{L}$ polifenol konsantrasyonunun sistemi inhibe ettiği vurgulanarak $1 \mathrm{~g} / \mathrm{L}$ polifenol konsantrasyonunun geçilmemesini tavsiye etmişlerdir. ZK'ya adaptasyonun sağlanması halinde adaptasyonsuz duruma göre $1 \mathrm{ve} 2 \mathrm{~g} / \mathrm{L}$ polifenol konsantrasyonlarında sırasıyla $\% 70$ ve $\% 300$ oranında metan veriminin arttığını bildirmişlerdir. Ayrıca yüksek organik yüklerde adaptasyonun kademeli olarak yapılmasını tavsiye etmişlerdir. Genel olarak ZK'daki polifenollerin konsantrasyonu 0,5 ila $25 \mathrm{~g} / \mathrm{L}$ arasında değişmektedir $[14,17,54]$. Ancak, halihazırda 0,5-2 g/L arasındaki polifenol konsantrasyonlarında metan üretiminin azaldığ 1 ifade edilmiştir. Buna göre, ham ZK'nın diğer organik substratlarla birlikte anaerobik arıtmaya tabi tutulması veya anaerobik reaktöre sınırlı yüklerle besleme yapılması gerekmektedir [17]. Bu nedenle, yukarıda bahsedilen problemler deneysel çalışmada aşı çamurunun adaptasyonu ve ham ZK'nın seyreltilmesi ile aşılmaya çalışılmıştır.

Seyreltilmiş ZK üzerinde laboratuvar ve pilot ölçekli deneylerde, mezofilik şartlardaki anaerobik proseste $4 \mathrm{~kg} \mathrm{KOI} / \mathrm{m}^{3} /$ gün organik yükten düşük konsantrasyonlarda yüksek arıtma verimlerinin (\%80-85) gerçekleştiği bildirilmiştir [14]. Özellikle başlangıç aşamasında ZK'nın seyreltilmesi önerilerek, besin ve alkalinite ilave edilmesinin gerekliliği vurgulanmıştır [34]. Başka bir çalışmada, ZK'nın anaerobik arıtımında giriş KOİ'si $1 \mathrm{~g} / \mathrm{L}$ 'nin üzerinde olduğunda biyogaz üretiminde inhibisyon görüldüğü ifade edilmiştir [14].

Bu çalışmada, HBS'nin 10 gün ve OYO'nun $1 \mathrm{~kg} \mathrm{KOI} / \mathrm{m}^{3} /$ gün olduğu anaerobik süreçte son 25 günlük durum dikkate alındığında \%75,6 $( \pm 14,2)$ oranında bir KOİ gideriminin olduğu gözlemlenmiştir. Toplam katı madde (TKM) ve uçucu katı madde (UKM) giderme verimlerinin yarı sürekli besleme periyodu boyunca sırasıyla ortalama \%72,3 ve \%74,4 olduğu tespit edilmiştir. Şekil 2'de görüleceği üzere reaktöre $10000 \mathrm{mg} / \mathrm{L}$ konsantrasyonda KOİ beslemesi yapılırken çıkıştaki KOİ konsantrasyonunun yaklaşık $311 \mathrm{mg} / \mathrm{L}$ 'ye kadar düştüğü görülmüştür. Çalışmada son 13 gün içerisinde 2 gün haricinde çıkış suyu KOİ konsantrasyonunun $1815 \mathrm{mg} / \mathrm{L}$ 'nin altında, son 5 günde ise bu değerin $924 \mathrm{mg} / \mathrm{L}$ 'den aşağıda olduğu tespit edilmiştir.

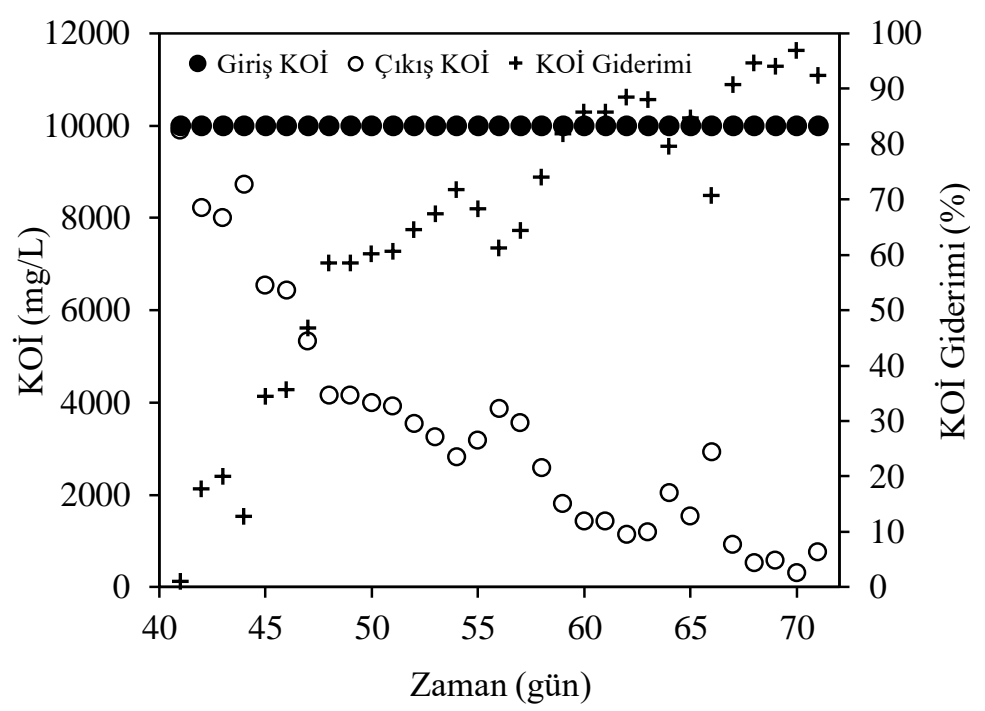

Şekil 2. Anaerobik reaktör giriş-çıkış KOİ konsantrasyonları ve KOİ giderim verimi

Gün bazlı değerlendirme yapıldığında maksimum KOİ giderim veriminin yaklaşık olarak \%97 civarında olduğu, son 5 ve 13 günde ise giderim veriminin sırasıyla $\% 94$ ve $\% 87$ olduğu tespit edilmiştir. Yarı sürekli besleme periyodunun özellikle ilk 4 gününde arıtma verimi, adaptasyon periyodunda yapılan beslemedeki ZK'nın içerisinde bulunan yağlı atıkların reaktörün çıkış yapısında birikerek reaktörden ayrılmasından dolayı düşük olduğu düşünülmektedir. Şekil 2 incelendiğinde 54-57 ve 63-66 günleri arasında arıtma verimindeki düşüş yönlü seyirlerin sebebinin bu günlerde baz ilavesinin arttırılmasından kaynaklı olduğu düşünülmektedir. Baz ilavesi yapıldıktan sonra, besleme suyu ile anaerobik çamur karıştığında hızlı bir reaksiyon gerçekleşmekte ve bu durum reaktör içi sıvısını 
bulandırmakta hatta tabanda olan anaerobik çamurun bir kısmını reaktörün çıkış bölgesine doğru taşımaktadır. Bu nedenle de bu durumun çıkış suyu KOİ konsantrasyonunu artırdığı düşünülmektedir. Anaerobik arıtma çalışmalarında vurgulandığ 1 gibi $[44,55]$ bu çalışmada da azot ve fosfor giderimi ihmal edilebilir düzeylerde gerçekleşmiştir. Anaerobik sistemlerin nütrientleri çok düşük seviyelerde arıtabildiği bilindiği için azot ve fosforda da düşük arıtma veriminin olması beklenen bir durumdur. Anaerobik sistemdeki azot ve fosfor giderimi, yeni biyokütle üretimi ve nütrientlerin reaktör içerisinde kalmasından dolayı gerçekleşmektedir [46]. Ayrıca bazı durumlarda reaktör içerisinden çamur kaçışı olması durumunda çikıştaki azot fosfor konsantrasyonu giriş konsantrasyonundan yüksek çıkabilmektedir. ZK'nın anaerobik olarak arıtıldığı rektörün çıkış suyu özellikleri Tablo 2'de verilmiştir.

Tablo 2. Anaerobik reaktör çıkış suyunun fizikokimyasal özellikleri

\begin{tabular}{lc}
\hline Parametreler & Değerler \\
\hline $\mathrm{pH}$ & $6,63 \pm 0,19$ \\
$\mathrm{KOI}(\mathrm{mg} / \mathrm{L})$ & $2321 \pm 1314$ \\
$\mathrm{TKM}(\mathrm{mg} / \mathrm{L})$ & $1785 \pm 857$ \\
$\mathrm{UKM}(\mathrm{mg} / \mathrm{L})$ & $1237 \pm 551$ \\
Alkalinite $(\mathrm{mg} \mathrm{CaCO} / \mathrm{L})$ & $712 \pm 255$ \\
$\mathrm{TKN}(\mathrm{mg} / \mathrm{L})$ & $81,4 \pm 28,8$ \\
$\mathrm{NH}_{3}-\mathrm{N}(\mathrm{mg} / \mathrm{L})$ & $21,8 \pm 6,57$ \\
$\mathrm{TP}(\mathrm{mg} / \mathrm{L})$ & $59,3 \pm 9,3$ \\
$\mathrm{PO}_{4}-\mathrm{P}(\mathrm{mg} / \mathrm{L})$ & $45,9 \pm 6,92$ \\
\hline
\end{tabular}

Anaerobik sistemin pH'^ $\mathrm{NaOH}$ çözeltisi ile ideal değerlere $(6,8-7,2)$ yakın tutulmaya çalış1lsa da, reaktörün pH'ının sürekli olarak düşmeye meyilli olduğu gözlenmiştir. Bu çalışmada anaerobik proses için ZK'nın düşük alkalinite seviyeleri özellikle zorlayıcı olmuştur. Şekil 3 (a)'da görüleceği üzere adaptasyon safhasının 34. gününde 5,4 olarak ölçülen $\mathrm{pH}$ seviyesini yükseltmek için $225 \mathrm{~mL}$ $\mathrm{NaOH}(1 \mathrm{~N})$ ilavesi ile $\mathrm{pH}$ değeri 7,2 seviyesine çıkarılmıştır. Ancak yarı sürekli beslemenin yapıldığ ikinci periyodun başlangıcına kadar $\mathrm{pH}$ tekrar düşerek 6,26 seviyesine gerilemiştir. Beslemenin yapılması ile beraber $\mathrm{pH}$ 'ı 6,7 seviyesine yükseldiği görülse de 45 . günde tekrardan $\mathrm{pH}$ düşerek 6,26 seviyelerine gerilediği gözlemlenmiştir. Baz ilavesiz bu yükselişin reaktör içi çamurun manyetik balık ile karıştırılmasından dolayı olduğu düşünülmektedir. 45. günde $3 \mathrm{~mL} \mathrm{NaOH}(1 \mathrm{~N})$ çözeltisi ilave edilmesine rağmen 46. günde $\mathrm{pH}$ değerinin 6,3 seviyesine düştüğü gözlemlenmiş ve bunun üzerine 4 $\mathrm{mL} \mathrm{NaOH}(1 \mathrm{~N})$ çözeltisi ilave edilmiştir. Bu miktarların tesirinin olmadı anlaşıldığından 47. günden 53. güne kadar $12 \mathrm{~mL} \mathrm{NaOH}(1 \mathrm{~N})$ çözeltisi ilave edilmiştir. Bu durumda ise yavaş bir artış izlenmiş bu nedenle $\mathrm{pH}$ yükselişini hızlandırmak için 53 ve 54. günlerde $16 \mathrm{~mL} \mathrm{NaOH}(1 \mathrm{~N})$ çözeltisi ilave edilmiştir. Bu süreçten sonra 61. güne kadar reaktör içi pH'nın yükseldiği gözlemlenmiş ancak uygun baz ilavesini test etmek maksadı ile $\mathrm{NaOH}$ çözeltisi ilavesi 8 mL'ye düşürülmüsstür. 60 ve 61 . günde $\mathrm{NaOH}$ çözeltisi ilavesi 4mL'ye düşürülmüş ancak reaktör içi $\mathrm{pH}$ değerinin düşüş seyrine geçtiği gözlemlenmiştir. Bunun üzerine tekrar $8 \mathrm{~mL}$ besleme yapılmış ancak istenen $\mathrm{pH}$ aralığına ulaşılamamıştır. Daha sonra 68. günde tekrar $12 \mathrm{~mL} \mathrm{NaOH}$ çözeltisi beslenmeye başlanmıştır. Çalışmada ilave edilen $\mathrm{NaOH}$ çözeltisi miktarına göre değişen $\mathrm{pH}$ değerlerine bakıldığında (Şekil 3a) 6,15 L hacme sahip olan reaktöre 10 günlük HBS ve $1 \mathrm{~kg} \mathrm{KOİ} / \mathrm{m}^{3} /$ gün OYO beslemesinin yapıldığı durumda $12 \mathrm{~mL} \mathrm{NaOH}(1 \mathrm{~N})$ çözeltisi ilavesinin en uygun $\mathrm{NaOH}$ çözeltisi dozu olduğu tespit edilmiştir.

Çıkış suyu pH değerleri incelendiğinde genel olarak pH seviyesinin 50. güne kadar reaktör içi $\mathrm{pH}$ seviyesinden düşük 50. günden sonra ise reaktör içi $\mathrm{pH}$ seviyesinden yüksek olduğu gözlemlenmiştir. Bu durumun ilave edilen bazın reaktörün üst kısmındaki duru halde bulunan sıvı fazla daha iyi bir etkileşimde olmasından ve oluşan amonyakla beraber $\mathrm{NaOH}$ çözeltisinin biyogaz baloncukları ile beraber yukarı yönlü taşınmasından kaynaklı olduğu düşünülmektedir. ZK besleme sıvisı ve anaerobik prosesteki asitojen safhasında oluşan uçucu yağların asiditesine karşın anaerobik çamurun kendine özgü ( $2336 \mathrm{mg} \mathrm{CaCO} / \mathrm{L}$ ) alkalinitesi $\mathrm{pH}$ 'ın hızlı ve sert düşüşüne mani olmakta buda sisteme müdahale için gerekli kontrol zamanını sağlamaktadır. Anaerobik mikroorganizmalar için optimum alkalinitenin 1000-4000 (2000) $\mathrm{mg} \mathrm{CaCO}_{3} / \mathrm{L}$ olduğu bildirilmiştir [56].

Şekil 3 (b)'de günlük biyogaz üretimi, $\mathrm{CH}_{4}$ ve $\mathrm{CO}_{2}$ oranı ile birlikte verilmiştir. Çalışmada adaptasyon periyodunda ve yarı sürekli beslemenin yapıldığı periyotta günlük ortalama biyogaz üretimi 
sırasıyla $424 \mathrm{~mL}$ ve $2256 \mathrm{~mL}$ olmuştur. Adaptasyon döneminde biyogazın metan içeriği \%17-66 aralığında değişmiş ve ortalama olarak yaklaşık \%53 oranında olduğu tespit edilmiş ve 15 . günden baz $(\mathrm{NaOH})$ ilavesinin yapıldığ 14 . güne kadar \%57'nin altına düşmemiştir. Yarı sürekli besleme döneminde ise biyogazın metan içeriği \%49,9-63,8 aralığında değişmiş ve ortalama olarak yaklaşık $\% 59,7$ oranında olduğu belirlenmiştir.

(a)
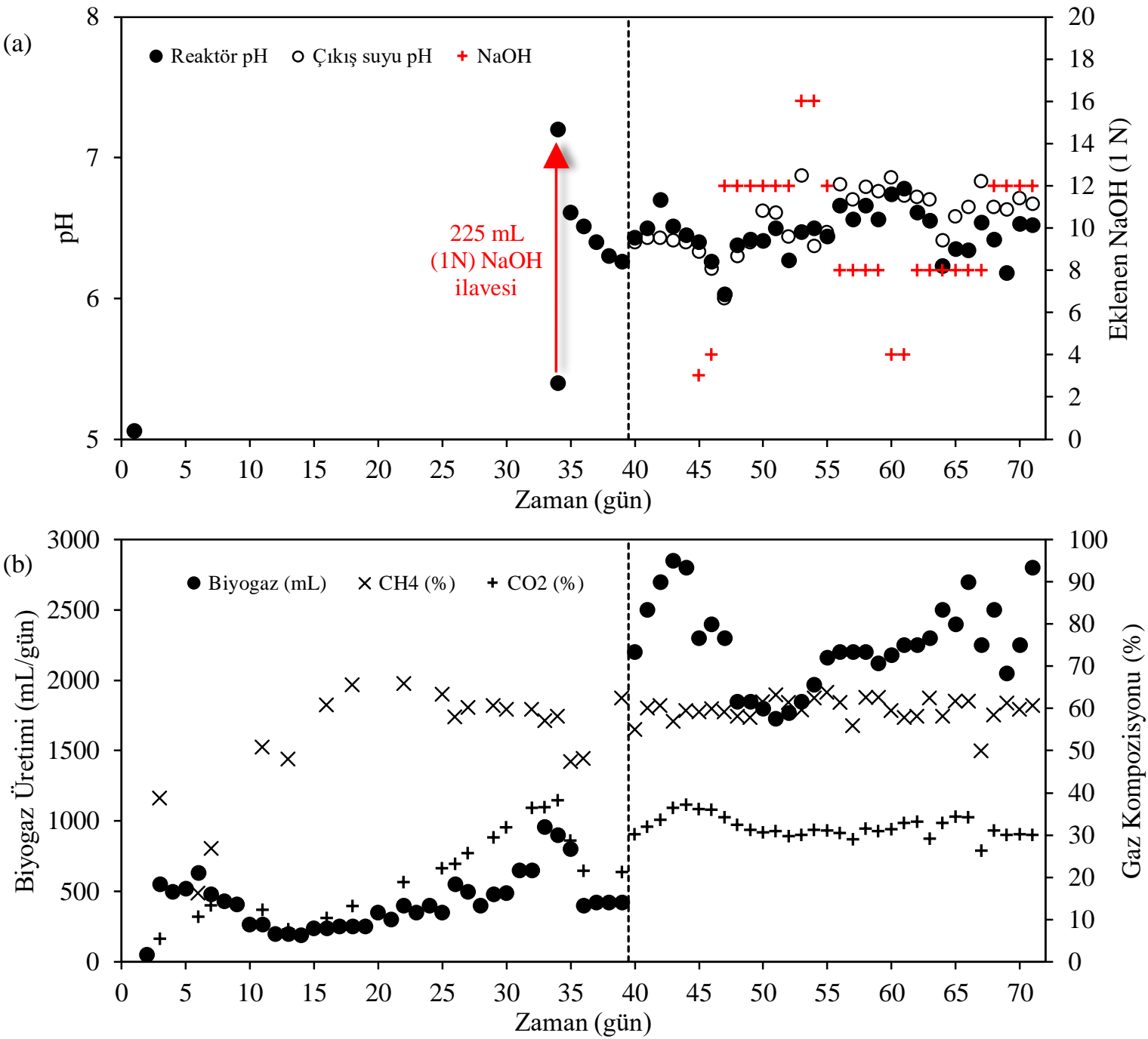

Şekil 3. Anaerobik proses boyunca eklenen $\mathrm{NaOH}(1 \mathrm{~N})$ çözeltisi miktarına göre reaktör içinde ve çıkış suyunda $\mathrm{pH}$ değişimi (a) ve günlük biyogaz üretimi ve biyogaz kompozisyonu $\left(\% \mathrm{CH}_{4}, \% \mathrm{CO}_{2}\right)(\mathrm{b})$

Adaptasyon safhasında yarı yarıya aşı çamuru ZK karışımı reaktöre doldurulduktan sonra 6. güne kadar yaklaşık günde 500-630 mL arasında biyogaz üretimi gerçekleşmiştir. Bu günden sonra 14 . güne kadar biyogaz üretimi düşerek günlük $190 \mathrm{~mL}$ seviyelerine gerilemiştir. Aynı zaman sürecinde biyogazın metan içeriği yaklaşık olarak \%60 mertebelerine ulaşmıştır. Biyogazın $\mathrm{CO}_{2}$ oranı ise 7. günde $\% 14$ seviyesine çıarken 14. günde $\% 7$ seviyelerine gerilemiştir. Biyogaz üretimi 15. günden 34 . güne kadar yaklaşık $900 \mathrm{~mL} /$ gün seviyelerine çıkmış, baz ilavesi yapıldıktan sonra adaptasyon periyodunun sonuna kadar yaklaşık $400 \mathrm{~mL} /$ gün seviyelerinde seyretmiştir. Bu süreçte biyogazın metan içeriği $\% 60$ 'lardan $\% 58$ seviyesine düşmüş, baz ilavesinden sonraki iki gün \%48 civarında ölçülmüş ve 39 . günde ise biyogazın metan içeriğinin tekrar \%62 seviyelerinde olduğu tespit edilmiştir. Ani baz yüklemesi metan üretiminin yaklaşı $\% 10$ oranında, $\mathrm{CO}_{2}$ üretiminin ise yaklaşık olarak \%17 oranında azalmasına sebep olmuştur. $\mathrm{Bu}$ durum, kuvvetli $\mathrm{NaOH}(1 \mathrm{~N})$ çözeltisi ile bazı metanojen bakterilerinin direk teması sonrası kısmi inhibasyonun gerçekleşmesine bağlanabilir. $\mathrm{CO}_{2}$ oranının $\mathrm{CH}_{4}$ oranından daha fazla düştüğü gözlemlenmiştir. $\mathrm{Bu}$ düşüş ise kısmi bakteri inhibasyonunun yanında $\mathrm{NaOH}$ çözeltisinin $\mathrm{CO}_{2}$ 'yi kimyasal absorbsiyon ile tutmasından kaynaklandığı düşünülmektedir. Aynı süreçte 
biyogazın $\mathrm{CO}_{2}$ içeriği 34. günde \%38 seviyesine çıkmış baz ilavesi sonrasında ise adaptasyon periyodunun sonuna kadar bu değer \%21 seviyelerine kadar gerilemiştir. ZK'nın dengesiz bir substrat olduğu ve toksisitesinin anaerobik prosesin oluşumuna izin vermediği bazı çalışmalarda vurgulanmıştır $[32,37]$. Ancak, farklı çalışmalarda ZK'nın klasik dezavantajlarının anaerobik sistem içerisinde bir şekilde çözümlenebildiği ve beslenen ZK'nın önemli bir kısmının biyolojik dönüşümünün gerçekleştiği ifade edilmiştir [30]. Bununla birlikte giderilemeyen renk ve KOİ için ek kimyasal arıtma yöntemleri uygulanabilir [2].

Yar1 sürekli besleme dönemine geçildiğinde ilk beslemeden sonraki gün $2200 \mathrm{~mL} /$ gün olan biyogaz üretimi 44. günde $2850 \mathrm{~mL} / g u ̈ n$ ile en yüksek seviyesine çıkmış daha sonra ise 51 . güne kadar $1730 \mathrm{~mL} /$ gün seviyesine düşmüştür. İlk beslemeden sonraki bu yükseliş durumu genel olarak anaerobik proseslerde görülen bir durumdur. Bu süreçten sonra günlük biyogaz üretimi 64. güne kadar yavaş ve sürekli bir yükselme eğilimi ile $2500 \mathrm{~mL}$ seviyesine çıkmıştır. Son 7 günlük süreçte 2050-2800 mL/gün arasında dalgalı bir biyogaz üretimi gözlemlenmiştir. Yarı sürekli besleme döneminde biyogazın $\mathrm{CH}_{4}$ ve $\mathrm{CO}_{2}$ içeriğinin ortalama olarak sırasıyla $\% 59,7( \pm 2,8)$ ve $\% 31,9( \pm 2,4)$ olduğu tespit edilmiştir. Biyogazın $\mathrm{CO}_{2}$ oranı 40 . günde $\% 30$ seviyelerinde iken 44 . günde yükselerek $\% 37$ oranına çıkmıştır. 45. günde baz ilavesinin başlaması ile birlikte bu oran düşmüş ve 50 . günden sonra ortalama $\% 30,9$ seviyelerinde seyretmiştir. Burada da $\mathrm{CO}_{2}$ 'nin bir kısmının $\mathrm{NaOH}$ ile kimyasal olarak absorblandığ düşünülmektedir. $\mathrm{Bu}$ çalışmada biyogaz üretimi ile biyogazın $\mathrm{CH}_{4}$ ve $\mathrm{CO}_{2}$ bileşiminin son 25 günde ortalama olarak sirasiyla $2177( \pm 279) \mathrm{mL} /$ gün ile $\% 59,96( \pm 2,94)$ ve $\% 31,14( \pm 1,82)$ olduğu tespit edilmiştir. Kümülatif biyogaz üretiminin adaptasyon periyodunda $16110 \mathrm{~mL}$ (39 gün) ve yarı sürekli besleme döneminde ise $72180 \mathrm{~mL}$ (32 gün) olduğu belirlenmiştir. Buna göre gözlemlenen biyogaz verimleri adaptasyon periyodunda ve yarı sürekli besleme sürecinde sirasıyla 537 ve $367 \mathrm{~mL}$ biyogaz /

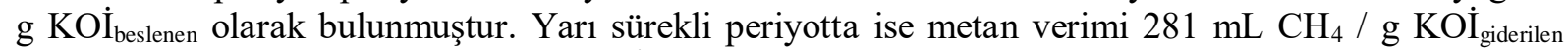
olarak tespit edilmiştir. Bu değer, $1 \mathrm{~g}$ KOİ'nin $35^{\circ} \mathrm{C}$ ve 1 atm' de teorik $\mathrm{CH}_{4}$ eşdeğeri olan $395 \mathrm{~mL}$ [57] ile kıyas edildiğinde deneysel çalışmanın başarılı olduğu düşünülmektedir. Sadece ZK'nın anaerobik olarak arıtılması durumunda azot ilavesi gerektiği vurgulanmış ve optimal arıtma için KOİ:N oranının 61:1 - 42:1 aralı̆̆ında olması gerektiği bildirilmiştir [30].

Karmaşık yağ çıkarma işlemlerinden geçen zeytin yüksek miktarda toksik ve biyolojik olarak zor parçalanabilen maddelerin varlığı nedeniyle, proses sonrası oluşan ZK'nın istenen düzeyde anaerobik olarak arıtılabilmesi için mutlaka bir ön işleme tabi tutulması gerekmektedir. Bununla birlikte, seyreltme ve baz ekleme gibi ön işlemlerde arıtma maliyetini arttırmaktadır. ZK genellikle uygun besin maddesi ve alkalinite dengesinden yoksun olduğundan farklı atıklar ile birlikte arıtımı bu olumsuzlukların azaltılmasına yardımcı olabileceği vurgulanmıştır. [43]. Çalışmada, ZK'nın yăg içeriğinin yüksek olması rektörde tıkanmalara ve yağın yüzerek reaktörü terk etmesi neticesinde arıtma veriminin düşmesine neden olmuştur. Ayrıca anaerobik reaktöre proses $\mathrm{pH}$ 'ını dengelemek için eklenen baz $(\mathrm{NaOH})$ yağ ile birleşerek sabunlaşmaya neden olmaktadır. Bu sabunlaşmalar rektörün sıvı ve gaz çıkış yapılarında tıkanmalara sebep olmuştur. Gerçek ölçekli tesislerde daha büyük çıkış yapılarının bulunmasından dolayı bu olumsuzluğun yaşanmayacağı düşünülmektedir. Ancak, bilindiği kadarıyla olumsuzlukların test edilebileceği ya da ekonomik fizibiletenin yapılacağı pilot ya da gerçek ölçekli bir tesis bulunmamaktadır. Zeytinyağı işleme fabrikalarının genellikle dönemsel olarak faaliyet göstermesi anaerobik arıtma sisteminin kurulmasında bir engel olarak görülmektedir. Ancak ZK yüksek organik yüke sahip olmasından dolayı önemli bir biyogaz potansiyeline sahiptir. Ayrıca, anaerobik arıtma yerinde çözüm üretebileceği için uygun bir alternatif olarak karşımıza çıkmaktadır. Zeytinyağı fabrikasının faaliyet göstermediği dönemler ZK'nın arıtılabilmesi için yeterli geniş bir zaman fırsatını sağlamaktadır. Buna ilaveten özellikle güneşlenme süresi yüksek olan Akdeniz ülkelerinde bulunan bu fabrikalardan çıkan ZK'nın mezofilik şartlarda arıtılabilmesi için gerekli olan ısının güneş enerjisinden sağlanma imkânının olması, anaerobik arıtma için uygun maliyetli bir çözüm olacaktır. Ayrıca, yerel imkânlar kullanılarak anaerobik arıtma tesislerinin kurulması ilk yatırım maliyetlerini önemli ölçüde düşürecektir [58].

\section{Sonuç ve Öneriler}

Laboratuvar ölçekli deneysel çalışmada 39 günlük bir adaptasyon periyodu anaerobik sistemi işletmeye alma esnasında oluşabilecek inhibasyonları önlemeye yardımcı olmuştur. Çalışmada, 1/8 oranında seyreltilerek yaklaşı olarak $10000 \mathrm{mg} / \mathrm{L}$ KOİ konsantrasyonunda $615 \mathrm{~mL}$ ZK'ya $1 \mathrm{~N} 12 \mathrm{~mL} \mathrm{NaOH}$ 
tampon baz ilavesi yapılarak anaerobik stabilite sağlanabilmiştir. Sonuç olarak anaerobik proses için gerekli olan işletme şartları sağlandığında reaktöre 10 günlük HBS ve $1 \mathrm{~kg} \mathrm{KOİ} / \mathrm{m}^{3} /$ gün OYO ile besleme yapılması durumunda \%75,6 $( \pm 14,2)$ oranında KOİ giderimi ile birlikte ZK'dan efektif olarak 2177 ( \pm 279$) \mathrm{mL} /$ gün biyogaz üretimi sağlanabilmektedir. Bu nedenle, anaerobik arıtma, ZK atıksuları için uygun bir alternatif olabilir, ancak alıcı sulara deşarj standartlarını karşılamak için ilave arıtma işlemine ihtiyaç duyulacaktır. Ayrıca, ZK'dan anaerobik koşullar altında dikkate değer miktarlarda biyogaz üretilebileceği sonucuna varılabilir. Bununla birlikte, gübre olarak kullanılabilen stabilize çıkış suyunun ekonomik değeri ve bazı çevresel sorunların giderilmesinden dolayı elde edilecek pozitif katkılar da dikkate alınmalıdır. Dolayısıyla, potansiyel bir organik kirletici olan zeytin işleme atıksularının anaerobik arıtma teknolojisi ile karlı bir enerji kaynağına dönüştürülerek sürdürülebilir ve daha temiz bir zeytinyağı üretiminin mümkün olduğu görülmektedir. Ancak, hâlâ tam bir pilot tesis eksikliği ve önerilen süreçlerin gerçek ölçekli ekonomik analizi bulunmamaktadır. Özellikle, bu endüstrinin büyük bir kısmının kurulduğu Akdeniz ülkelerinde ihtiyacı karşılayacak seviyede bulunan güneş enerjisinin anaerobik arıtma prosesinde kullanımı uygun maliyetli bir çözüm için önemli görülmektedir.

\section{Teşekkür}

Yazar bu çalışmayı finansal olarak destekleyen Adıyaman Üniversitesi Bilimsel Araştırma Projeleri Birimine teşekkür etmektedir (MÜFLAP/2017-0012).

\section{Yazarların Katkısı}

Makalede tüm katkı şahsıma aittir.

\section{Çıkar Çatışması Beyanı}

Yazarlar arasında herhangi bir çıkar çatışması bulunmamaktadır.

\section{Araştırma ve Yayın Etiği Beyanı}

Yapılan çalışmada, araştırma ve yayın etiğine uyulmuştur.

\section{Kaynaklar}

[1] Mert B.K., Yonar T., Kilic M.Y., Kestioglu K. 2010. Pre-treatment studies on olive oil mill effluent using physicochemical, Fenton and Fenton-like oxidations processes. Journal of Hazardous Materials, 174 (1-3): 122-128.

[2] Tufaner F. 2019. Evaluation of COD and color removals of effluents from UASB reactor treating olive oil mill wastewater by Fenton process. Separation Science and Technology, 1-12.

[3] TÜİK 2019. Türkiye İstatistik Kurumu, Bitkisel Üretim İstatistikleri, Zeytin Üretimi 1988-2018. http://www.tuik.gov.tr/PreTabloArama.do?metod=search\&araType=vt. (Erişim Tarihi: 24.12.2019).

[4] IOC 2018. International Olive Council, Market Newsletter No 126 - April 2018. 51st meeting of the Advisory Committee, http://www.internationaloliveoil.org/documents/viewfile/13437market-newsletter-april-2018. (Erişim Tarihi: 08.03.2019).

[5] UZZK 2019. Ulusal Zeytin ve Zeytinyağı Konseyi, 2019-2020 Üretim Sezonu Sofralık Zeytin ve Zeytinyağ 1 Rekoltesi Ulusal Resmi Tespit Heyeti Raporu. http://www.uzzk.org/Belgeler/UZZK_2019_2020_Turkiye_Rekolte_Raporu.pdf. (Erişim Tarihi: 28.04.2020).

[6] IOC 2019. International Olive Council, World olive oil figures, Production. https://www.internationaloliveoil.org/wp-content/uploads/2020/04/HO-W901-29-11-2019P.pdf. (Erişim Tarihi: 28.04.2020).

[7] Kiritsakis A., Shahidi F. 2017. Olives and Olive Oil as Functional Foods: Bioactivity, Chemistry and Processing. John Wiley \& Sons, 1-688. 
[8] García C.A., Hodaifa G. 2017. Real olive oil mill wastewater treatment by photo-Fenton system using artificial ultraviolet light lamps. Journal of Cleaner Production, 162: 743-753.

[9] Bernardi B., Benalia S., Zema D., Tamburino V., Zimbalatti G. 2017. An automated medium scale prototype for anaerobic co-digestion of olive mill wastewater. Information Processing in Agriculture, 4 (4): 316-320.

[10] Rocha C., Soria M., Madeira L.M. 2018. Thermodynamic analysis of olive oil mill wastewater steam reforming. Journal of the Energy Institute, 92 (5): 1599-1609.

[11] De Leonardis A., Macciola V., Iorizzo M., Lombardi S.J., Lopez F., Marconi E. 2018. Effective assay for olive vinegar production from olive oil mill wastewaters. Food Chemistry, 240: 437440.

[12] Hanafi F., Assobhei O., Mountadar M. 2010. Detoxification and discoloration of Moroccan olive mill wastewater by electrocoagulation. Journal of Hazardous Materials, 174 (1-3): 807-812.

[13] Justino C.I., Duarte K., Loureiro F., Pereira R., Antunes S.C., Marques S.M., Gonçalves F., Rocha-Santos T.A., Freitas A.C. 2009. Toxicity and organic content characterization of olive oil mill wastewater undergoing a sequential treatment with fungi and photo-Fenton oxidation. Journal of Hazardous Materials, 172 (2-3): 1560-1572.

[14] Niaounakis M., Halvadakis C.P. 2006. Olive Processing Waste Management: Literature Review and Patent Survey. Second Edition, Elsevier Science, 498p, Amsterdam (Netherlands).

[15] Turano E., Curcio S., De Paola M.G., Calabrò V., Iorio G. 2002. An integrated centrifugationultrafiltration system in the treatment of olive mill wastewater. Journal of Membrane Science, 209 (2): 519-531.

[16] Lucas M.S., Peres J.A. 2009. Removal of COD from olive mill wastewater by Fenton's reagent: Kinetic study. Journal of Hazardous Materials, 168 (2-3): 1253-1259.

[17] Calabrò P.S., Fòlino A., Tamburino V., Zappia G., Zema D.A. 2018. Increasing the tolerance to polyphenols of the anaerobic digestion of olive wastewater through microbial adaptation. Biosystems Engineering, 172: 19-28.

[18] El-Abbassi A., Kiai H., Raiti J., Hafidi A. 2014. Application of ultrafiltration for olive processing wastewaters treatment. Journal of Cleaner Production, 65: 432-438.

[19] Ochando-Pulido J.M., Martinez-Ferez A. 2018. Operation setup of a nanofiltration membrane unit for purification of two-phase olives and olive oil washing wastewaters. Science of the Total environment, 612: 758-766.

[20] Ochando-Pulido J., Stoller M., Di Palma L., Martinez-Ferez A. 2014. Threshold performance of a spiral-wound reverse osmosis membrane in the treatment of olive mill effluents from two-phase and three-phase extraction processes. Chemical Engineering and Processing: Process Intensification, 83: 64-70.

[21] Masi F., Bresciani R., Munz G., Lubello C. 2015. Evaporation-condensation of olive mill wastewater: Evaluation of condensate treatability through SBR and constructed Wetlands. Ecological Engineering, 80: 156-161.

[22] Sklavos S., Gatidou G., Stasinakis A.S., Haralambopoulos D. 2015. Use of solar distillation for olive mill wastewater drying and recovery of polyphenolic compounds. Journal of Environmental Management, 162: 46-52.

[23] Papaphilippou P.C., Yiannapas C., Politi M., Daskalaki V.M., Michael C., Kalogerakis N., Mantzavinos D., Fatta-Kassinos D. 2013. Sequential coagulation-flocculation, solvent extraction and photo-Fenton oxidation for the valorization and treatment of olive mill effluent. Chemical Engineering Journal, 224: 82-88.

[24] Hodaifa G., Gallardo P.A.R., García C.A., Kowalska M., Seyedsalehi M. 2019. Chemical oxidation methods for treatment of real industrial olive oil mill wastewater. Journal of the Taiwan Institute of Chemical Engineers, 7: 247-254.

[25] Chedeville O., Debacq M., Porte C. 2009. Removal of phenolic compounds present in olive mill wastewaters by ozonation. Desalination, 249 (2): 865-869.

[26] González-González A., Cuadros F. 2015. Effect of aerobic pretreatment on anaerobic digestion of olive mill wastewater (OMWW): An ecoefficient treatment. Food and bioproducts processing, 95: 339-345. 
[27] Galliou F., Markakis N., Fountoulakis M., Nikolaidis N., Manios T. 2018. Production of organic fertilizer from olive mill wastewater by combining solar greenhouse drying and composting. Waste Management, 75: 305-311.

[28] Ubay G., Ozturk I. 1997. Anaerobic treatment of olive mill effluents. Water Science and Technology, 36 (2-3): 287-294.

[29] Ochando-Pulido J., Pimentel-Moral S., Verardo V., Martinez-Ferez A. 2017. A focus on advanced physico-chemical processes for olive mill wastewater treatment. Separation and Purification Technology, 179: 161-174.

[30] Sampaio M., Gonçalves M., Marques I. 2011. Anaerobic digestion challenge of raw olive mill wastewater. Bioresource Technology, 102 (23): 10810-10818.

[31] Azbar N., Tutuk F., Keskin T. 2009. Biodegradation performance of an anaerobic hybrid reactor treating olive mill effluent under various organic loading rates. International Biodeterioration \& Biodegradation, 63 (6): 690-698.

[32] El-Gohary F., Tawfik A., Badawy M., El-Khateeb M.A. 2009. Potentials of anaerobic treatment for catalytically oxidized olive mill wastewater (OMW). Bioresource Technology, 100 (7): 21472154.

[33] McNamara C.J., Anastasiou C.C., O'Flaherty V., Mitchell R. 2008. Bioremediation of olive mill wastewater. International Biodeterioration \& Biodegradation, 61 (2): 127-134.

[34] Paraskeva P., Diamadopoulos E. 2006. Technologies for olive mill wastewater (OMW) treatment: a review. Journal of Chemical Technology and Biotechnology, 81 (9): 1475-1485.

[35] Mechich T., Sayadi S. 2005. Evaluating process imbalance of anaerobic digestion of olive mill wastewaters. Process Biochemistry, 40 (1): 139-145.

[36] Dareioti M.A., Dokianakis S.N., Stamatelatou K., Zafiri C., Kornaros M. 2010. Exploitation of olive mill wastewater and liquid cow manure for biogas production. Waste Management, 30 (10): 1841-1848.

[37] Gelegenis J., Georgakakis D., Angelidaki I., Christopoulou N., Goumenaki M. 2007. Optimization of biogas production from olive-oil mill wastewater, by codigesting with diluted poultry-manure. Applied Energy, 84 (6): 646-663.

[38] Martinez-Garcia G., Johnson A.C., Bachmann R.T., Williams C.J., Burgoyne A., Edyvean R.G.J. 2009. Anaerobic treatment of olive mill wastewater and piggery effluents fermented with Candida tropicalis. Journal of Hazardous Materials, 164 (2-3): 1398-1405.

[39] Orive M., Cebrián M., Zufía J. 2016. Techno-economic anaerobic co-digestion feasibility study for two-phase olive oil mill pomace and pig slurry. Renewable Energy, 97: 532-540.

[40] Al-Mallahi J., Furuichi T., Ishii K. 2016. Appropriate conditions for applying NaOH-pretreated two-phase olive milling waste for codigestion with food waste to enhance biogas production. Waste Management, 48: 430-439.

[41] Gharsallah N., Labat M., Aloui F., Sayadi S. 1999. The effect of Phanerochaete chrysosporium pretreatment of olive mill waste waters on anaerobic digestion. Resources Conservation and Recycling, 27 (1-2): 187-192.

[42] Dareioti M.A., Dokianakis S.N., Stamatelatou K., Zafiri C., Kornaros M. 2009. Biogas production from anaerobic co-digestion of agroindustrial wastewaters under mesophilic conditions in a twostage process. Desalination, 248 (1-3): 891-906.

[43] Gunay A., Karadag D. 2015. Recent developments in the anaerobic digestion of olive mill effluents. Process Biochemistry, 50 (11): 1893-1903.

[44] Tufaner F. 2020. Post-treatment of effluents from UASB reactor treating industrial wastewater sediment by constructed wetland. Environmental Technology, 41 (7): 912-920.

[45] Azbar N., Tutuk F., Keskin T. 2009. Effect of organic loading rate on the performance of an upflow anaerobic sludge blanket reactor treating olive mill effluent. Biotechnology and Bioprocess Engineering, 14 (1): 99-104.

[46] Tufaner F. 2015. Büyükbaş hayvansal atıkların biyometanizasyon süreçlerinin iyileştirilmesinin araştırılması. Doktora Tezi, Yıldız Teknik Üniversitesi, Fen Bilimleri Enstitüsü, İstanbul.

[47] Tufaner F., Avşar Y., Gönüllü M.T. 2017. Modeling of biogas production from cattle manure with co-digestion of different organic wastes using an artificial neural network. Clean Technologies and Environmental Policy, 19 (9): 2255-2264. 
[48] APHA 2012. Standard Methods for Examination of Water and Wastewater. 22nd ed. edited by Rice W.Eugene, Baird B. Rodger, Eaton D.Andrew., American Public Health Association (APHA), American Water Works Association, Water Environmental Federation. Washington, DC, USA.

[49] Rajesh Banu J., Arulazhagan P., Adish Kumar S., Kaliappan S., Lakshmi A.M. 2015. Anaerobic co-digestion of chemical-and ozone-pretreated sludge in hybrid upflow anaerobic sludge blanket reactor. Desalination and Water Treatment, 54 (12): 3269-3278.

[50] Forster-Carneiro T., Perez M., Romero L.I. 2008. Influence of total solid and inoculum contents on performance of anaerobic reactors treating food waste. Bioresource Technology, 99 (15): 6994-7002.

[51] Lee E., Bittencourt P., Casimir L., Jimenez E., Wang M., Zhang Q., Ergas S.J. 2019. Biogas production from high solids anaerobic co-digestion of food waste, yard waste and waste activated sludge. Waste Management, 95: 432-439.

[52] Pandey P.K., Ndegwa P.M., Soupir M.L., Alldredge J.R., Pitts M.J. 2011. Efficacies of inocula on the startup of anaerobic reactors treating dairy manure under stirred and unstirred conditions. Biomass \& Bioenergy, 35 (7): 2705-2720.

[53] Guendouz J., Buffiere P., Cacho J., Carrere M., Delgenes J.P. 2010. Dry anaerobic digestion in batch mode: Design and operation of a laboratory-scale, completely mixed reactor. Waste Management, 30 (10): 1768-1771.

[54] Yangui A., Abderrabba M. 2018. Towards a high yield recovery of polyphenols from olive mill wastewater on activated carbon coated with milk proteins: Experimental design and antioxidant activity. Food Chemistry, 262: 102-109.

[55] Yetilmezsoy K., Sakar S. 2008. Improvement of COD and color removal from UASB treated poultry manure wastewater using Fenton's oxidation. Journal of Hazardous Materials, 151 (2-3): 547-558.

[56] Öztürk İ. 2007. Anaerobik Arıtma ve Uygulamaları. Genişletilmiş 2 Baskı, Su Vakfı Yayınları, İstanbul.

[57] Tchobanoglus G., Burton F., Stensel H.D. 2003. Wastewater engineering: Treatment and reuse. Fourth Edition, Metcalf \& Eddy Inc. McGraw-Hill, New York, USA.

[58] Tufaner F., Avsar Y. 2019. Economic analysis of biogas production from small scale anaerobic digestion systems for cattle manure. Environmental Research and Technology, 2 (1): 6-12. 